\title{
Educating the Humanitarian Engineer
}

Kevin M. Passino The Ohio State University 


\section{Outline}

- Volunteerism/humanitarianism is required for engineering professionalism?

- Universities are responsible for development of the profession

- Educating the volunteer/humanitarian engineer is a university responsibility:

$\square$ Strategy 1: Expand ethics and professionalism treatment

$\square$ Strategy 2: Hands-on volunteerism via a student organization

$\square$ Strategy 3: Humanitarian Engineering course/minor

- Concluding remarks 


\section{Strategy 1: Expand Ethics and Professionalism Treatment}

- Course topical outline (professionalism, codes of ethics, moral frameworks, eng. as social experimentation, safety/risk, case studies, workplace, honesty, environmental ethics, global issues)

- How to augment typical textbook treatments...

- Profession: "Pursuit of a learned art in the spirit of public service" (ASCE)

- Webster's Dictionary: “... a kind of work which has for its prime purpose the rendering of a public service."

- Public service is a critical part of being a professional! 


\section{Two routes to public service}

- Employment + Service to Profession: Competence ("go the extra mile" to do good work), service to colleagues, service to profession, etc.

- Community service: Local/international service, charitable organizations, disadvantaged groups, non-profits, educating public about profession, etc.

- Are both required? For the profession, yes, for the individual not always. 


\section{Codes of Ethics}

- NSPE:

$\square$ "Hold paramount the safety, health, and welfare of the public" (engineers must help the poor?)

$\square$ "Engineers are encouraged to adhere to the principles of sustainable development in order to protect the environment for future generations."

- Role of "service" in codes, comparative:

$\square$ NSPE: "Engineers shall seek opportunities to participate in civic affairs; career guidance for youths; and work for the advancement of the safety, health, and well-being of their community."

$\square$ Others with similar statements: ASCE, ACM/IEEE Software Eng. Code

$\square$ Others have weak/no statements: AIChE, ASME, IEEE

- We need changes!

$\square$ Encourage, support, set group expectations,...

$\square$ Must prominently state our ideals! 


\section{Comparative professionalism}

- AMA: "A physician shall recognize a responsibility to participate in activities contributing to the improvement of the community and the betterment of public health."

- ABA: “... Every lawyer has a professional responsibility to provide legal services to those unable to pay. A lawyer should aspire to render at least (50) hours of pro bono publico legal services per year."

- Is there a pervasive "pro bono" spirit in engineering???

$\square$ Existing student volunteer activities (e.g., SWE, Tau Beta Pi, etc.)

$\square$ Existing practicing engineers' volunteerism (tutoring, etc.); identified as engineers? Do engineers/others view their services as essential?

$\square$ We need "engineering clinics" as infrastructure for volunteer engineers

$\square$ We need expanded "corporate citizenship programs" in corporations 


\section{Moral frameworks}

- Utilitarianism, rights/duty ethics, virtue ethics all support volunteerism?

- Community-oriented version of self-realization ethics:

$\square$ Promote professional development via integration of work and personal integrity

$\square$ Company supports engineer in service, engineer develops loyalty to company

$\square$ Need strong corporate citizenship programs! 


\section{Global Issues, World-Wide Communities...}

- Community design constraints (must teach this!)

$\square$ Know needs of community, get community involved, use local talent

$\square$ Appropriate technology, technology transfer, safety

$\square$ Cost, maintenance, and improvement

- Environment (sustainable development)

- Cultural exchange (efficiency vs. relationships)

- Globalization (learn about the competition)

- We need to educate "Global Citizens" 


\section{Strategy 2: Hands-On}

Volunteerism Via a Student

Organization

- OSU Engineers for Community Service (ECOS)

- Founded 2004, related organizations:

$\square$ Engineers Without Borders (EWB), USA, Univ. Colorado, Boulder

$\square$ Engineers for a Sustainable World (ESW)

$\square$ Engineering Projects in Community Service (EPICS), Purdue University +

$\square$ ETHOS, Univ. Dayton; Engineering World Health, Duke Univ.

$\square$ Chapters + others...

- Prime determinant of success - Students 


\section{Mission}

- Engineers for Community Service (ECOS) promotes life-long professionalism via educational experiences in the uses of engineering skills for local and international community service projects. 


\section{ECOS is a College-Wide “Umbrella Organization"}

- Advisory Board with faculty and staff

- Seminar series (e.g., service project examples)

- Multiple parallel projects in progress across College of Engineering:

- ECOS web: http://ecos.osu.edu/ for project descriptions

- Key challenge: High-tech vs. "grunt work" 


\section{Volunteerism project ideas}

- Drinking water filtration, waste treatment (low cost, effective yet without adverse environmental impact)

- Agriculture (improve yield, irrigation)

- Low-cost housing (local materials, portability for refugees)

- Electricity generation, wind and solar power, solar cooker, lighting (renewable energy sources, low-cost solutions to basic needs)

- Computer technology (education support, career-development)

- Communications technology (promote democracy, market price information)

- Medical technology, telemedicine (promote healthcare access and quality) 


\section{Projects}

- Columbus/Domestic:

$\square$ Wonders of Our World (WOW): Science education for K-5

$\square$ TechCorps, Ohio: Technology for disadvantaged schools

$\square$ OSU FIRST robotics

$\square$ Notre Dame Alumni Club Computer Software Education Project involvement

$\square$ Explorer Post

$\square$ Wheel-chair ramp project

$\square$ Retirement home, computer education project

$\square$ Wheel chair ramp project

\section{WOW program students}

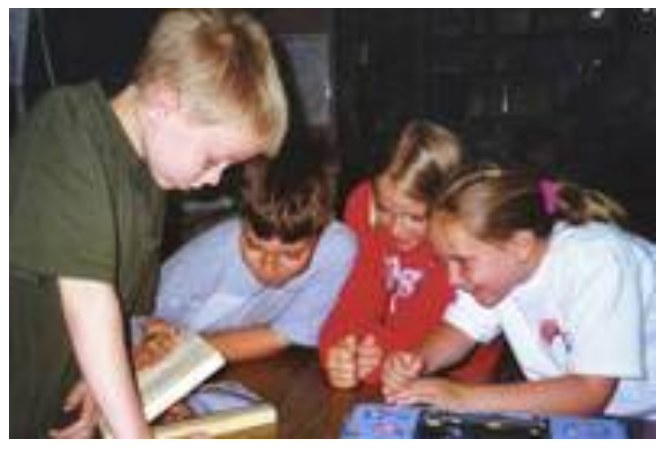

OSU engineering students with local high school students working on a robot

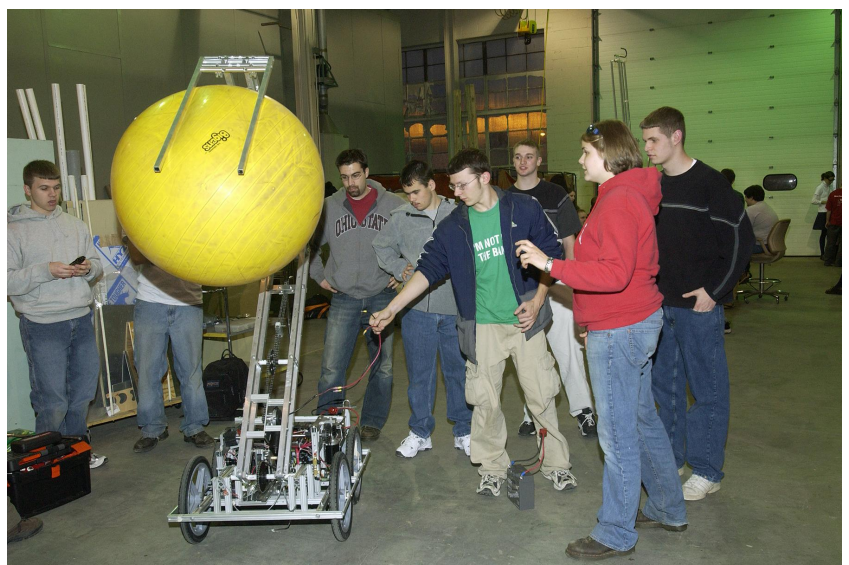




\section{Projects}

- International (completed):

A low-cost control system experiment

$\square$ Low-cost laboratory development for highereducation

$\square$ Casa de Maria y el Niño orphanage, computer donation and education, Medellín, Colombia (Summer 2004)

$\square$ Design courses in lowcost housing and drinking water purification
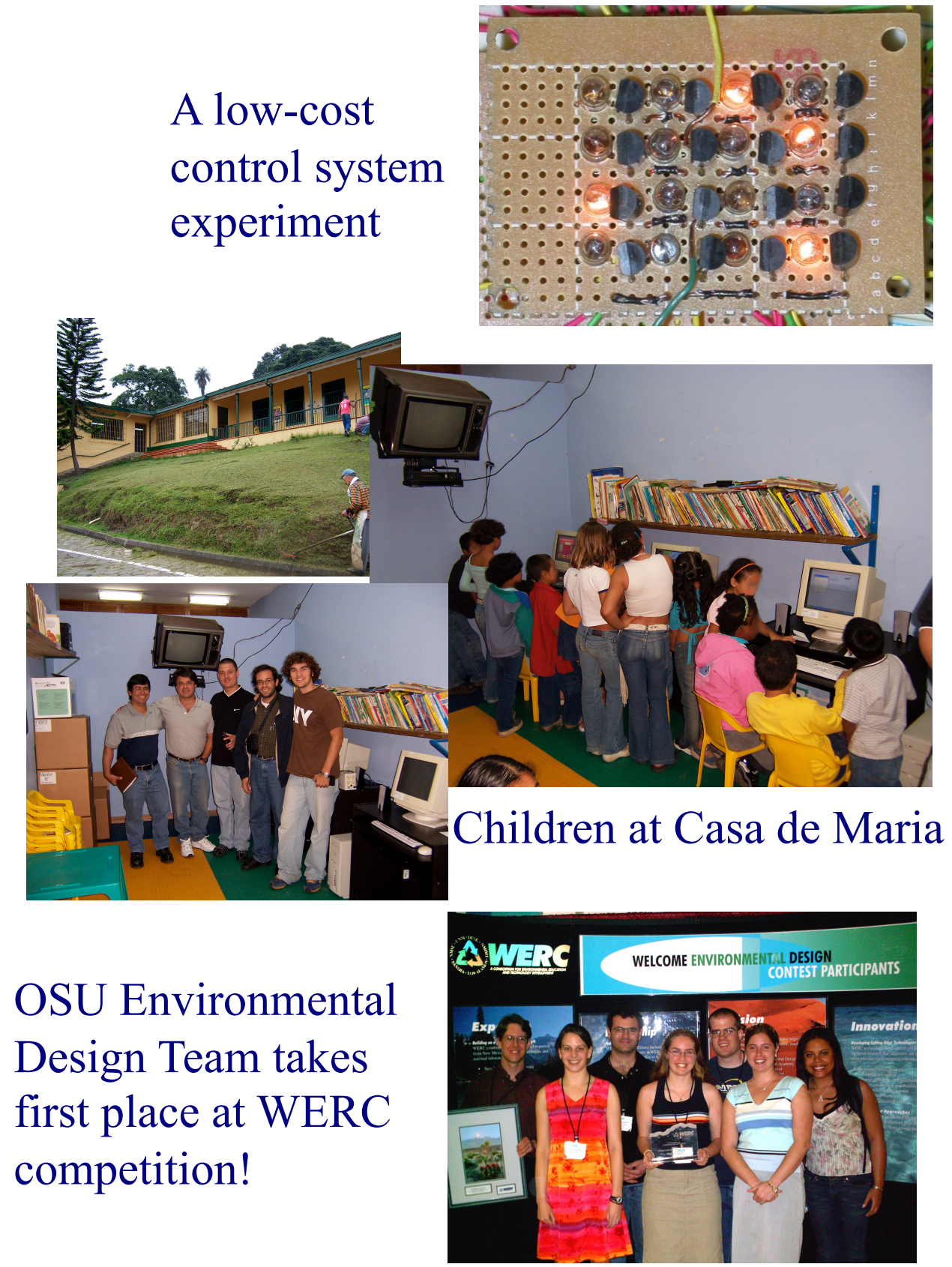
- International project (Spring Breaks since 2005):

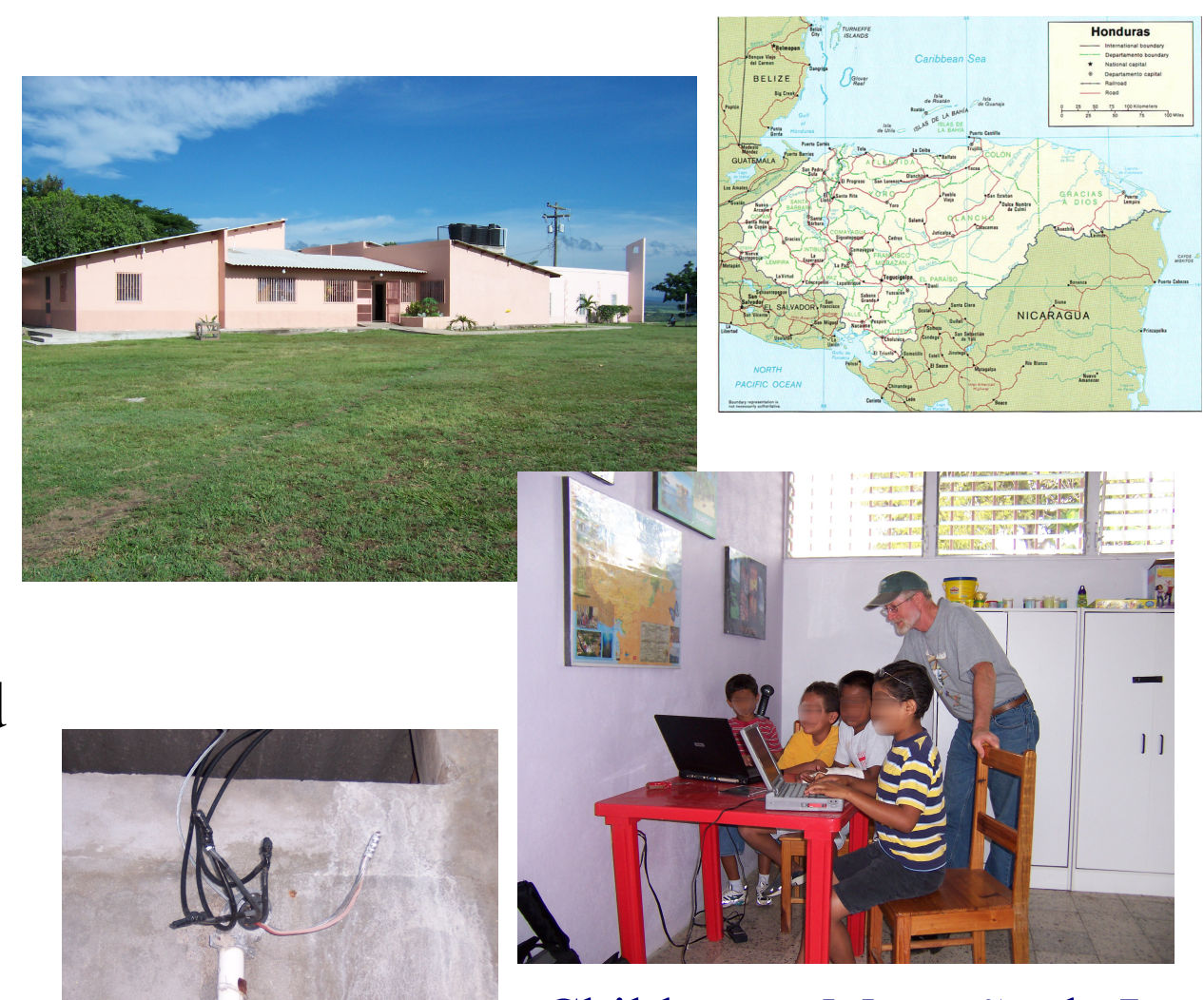

Montaña de Luz, HIVI AIDS orphanage in Honduras

- Pre-project trip completed Summer 2004

- Web page

- Electrical wiring

- Administrative computers

- Children's computer lab

- Computer education

- Assess communication problems

\section{Also Choluteca project}
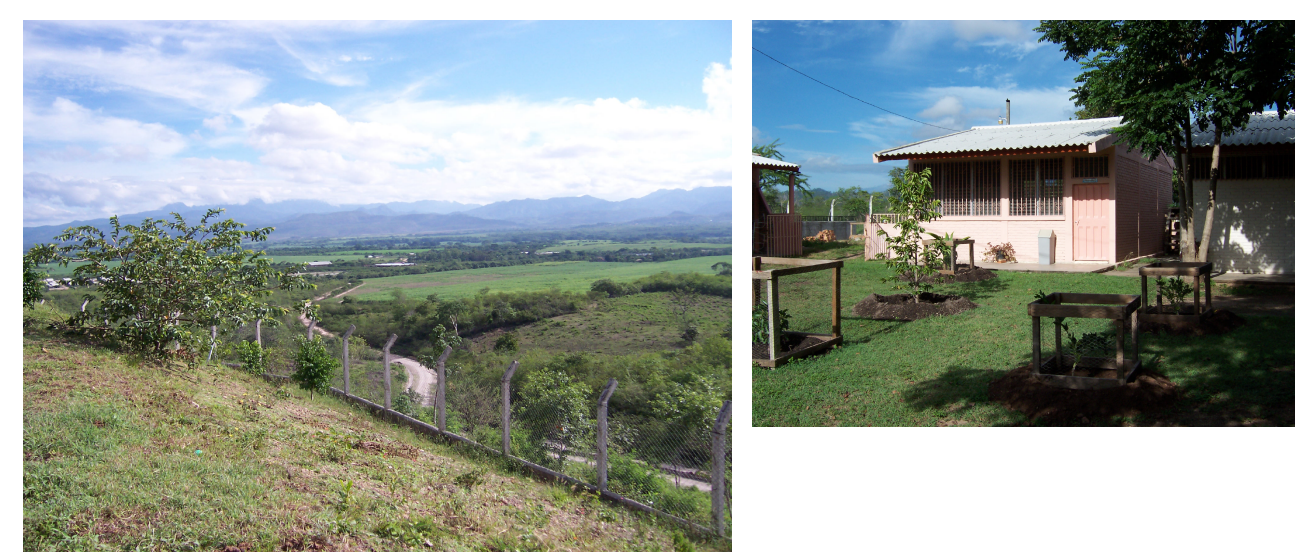


\section{Strategy 3: Humanitarian Engineering Curriculum}

- Humanitarian Engineering Minor (to be proposed)

$\square$ For all majors in College of Engineering

$\square$ 3-4 courses in language, culture, international economics/business, politics, development/poverty, sustainability/environment

$\square$ Integrative course "Humanitarian Engineering"

$\square$ Project courses local, international (design+trip)

- Student interest:

$\square$ Humanitarian Engineering Scholars Program (live in dorm together, talks, etc.): 150 students/yr

$\square$ ECOS, EWB, ESW, etc. (projects/trips since 2005) 


\section{Humanitarian Engineering (proposed course, Spring 2014)}

- Week 1: Status of poverty and development world-wide, UN Millennium Development Goals, Technology and engineering in development

- Week 2: Social justice as rationale and goal for humanitarian engineering, Social justice, religious perspectives

- Week 3: Social justice, religious/secular

- Week 4: Social justice, secular perspectives 
- Week 5: Social justice and engineering ethics

- Week 6: Development strategies

- Week 7: Development strategies, implications for engineering for development

- Week 8: Engineering for community development

- Week 9: Extreme design constraints, "appropriate technology" 
- Week 10: Environment, pollution and climate change, environmental ethics, sustainable ("cradle-to-cradle" or "life-cycle") design

- Week 11: Cultural impact on engineering business, engineering ethics, technology design

- Week 12: Design implementation and iteration, reasons for failures of projects, examples 
- Week 13: Humanitarianism and the university: Research, curriculum, student organizations, inter-university collaboration for development, project trips, up-coming OSU project trips

- Week 14: Humanitarianism and the engineering enterprise: Technology policy, technology to promote social justice, technology for the poor, technology transfer, "race to the bottom", impact on engineering (e.g., sweatshops), weapons development/social justice 


\section{Comments on Course}

- Part of "service-learning" trend (across university)

- "Theory" part of theory-practice of humanitarian engineering

- 3 credit hours, 3 lectures/week, offered annually

- Prerequisites: Undergraduate/graduate engineering majors, architecture majors, first eng. course

- Assignments: Weekly home works, book report, midterm/final paper design project (integrative)

- Working already to put the course on-line 


\section{Wider University Program Development}

- Other related curricular programs at:

$\square$ Univ. Colorado, Boulder

$\square$ Colorado School of Mines

$\square$ Pennsylvania State University

$\square$ MIT (D-Lab)

- Development of other programs?

$\square$ Other US programs highly likely to develop (globalization + student interest are drivers)

$\square$ Best: Humanitarian Engineering courses/programs in developing countries, in the local language, given from a local perspective, using local expertise. 


\section{Humanitarian Engineering Program Here?}

- I volunteer to teach a short course here

- Desired audience:

$\square$ Professors (to teach the course here), Dept. Chairs/ Deans (who approve/support teaching)

$\square$ Practicing engineers (lead projects), students

- Desired outcomes:

$\square$ Regularly offered course on humanitarian engineering, humanitarian engineering minor, and/or use the on-line course?

$\square$ Projects:

- Professors, practicing engineers lead

- Involve OSU? Teach us problems, collaborate on solutions 


\section{Will such a program succeed?}

- Are your universities directed to serve your country? Does university funding (e.g., from the government) depend on that?

- University/professor/staff/practicing engineer support for humanitarian engineering is critical (part of duties?)

- Student interest drives curricular success! If you offer a course and no one signs up, it fails!

- Student perspective on an engineering career:

$\square$ Profit (support family, make company money)

$\square$ Humanitarian engineering career (support family? Jobs? NGOs? Government?)

$\square$ Do both? Have job for career/profit, plus in freetime do humanitarian engineering? 


\section{Concluding remarks}

1. Claim 1: Individual (group) professionalism is (is not) possible without volunteer service to the community

2. Claim 2: Universities are responsible for development of the profession and educating the volunteering engineer

3. Claim 3: Humanitarian Engineering is an important and growing field to support professional volunteerism

4. Claim 4: Critical need for infrastructure to support the volunteer engineer (university, industry, government)

- Reference:

$\square$ K.M. Passino, "Educating the Humanitarian Engineer" Science and Engineering Ethics Journal

$\square$ Paper at: http://www.ece.osu.edu/ passino/ professionalism.html 